\title{
Keefektifan model pembelajaran CORE dengan strategi konflik kognitif ditinjau dari prestasi belajar, berpikir kritis, dan self-efficacy
}

\author{
Sri Wahyuni Ningsih ${ }^{1 *}$, Sugiman 2 (i), Pika Merliza ${ }^{3}$, Uke Ralmugiz ${ }^{4}$ \\ ${ }_{1}^{1}$ Madrasah Aliyah Negeri 1 Kolaka, Kolaka, Indonesia \\ 2 Department of Mathematics Education, Universitas Negeri Yogyakarta, Yogyakarta, Indonesia \\ ${ }^{3}$ Department of Mathematics Education, Universitas Muhammadiyah Kupang, Kupang, Indonesia \\ ${ }^{4}$ Department of Mathematics Education, Institut Agama Islam Negeri Metro, Kota Metro, Indonesia \\ * Corresponding Author. E-mail: sw.ningsih592@gmail.com
}

ARTICLE INFO ABSTRACT

\section{Article History:}

Received: 22 Sept. 2020

Revised: 30 Sept. 2020

Accepted: 01 Dec. 2020

\section{Keywords:}

Model CORE,

Strategi konflik kognitif,

Berpikir kritis,

Self-efficacy,

Cognitive conflict strategies,

Mathematics achievement,

Critical thinking.

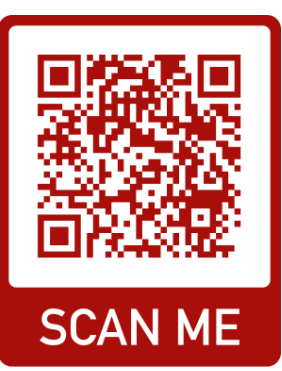

Penelitian ini bertujuan untuk menguji keefektifan model pembelajaran Connecting, Organizing, Reflecting, Extending (CORE) dengan strategi konflik kognitif ditinjau dari prestasi belajar, berpikir kritis, dan self-efficacy siswa. Jenis penelitian ini adalah quasi experiment dengan pretest-posttest nonequivalent group design. Populasi dalam penelitian ini adalah siswa kelas VIII SMP Negeri 3 Yogyakarta dan dipilih secara acak kelas VIII-C $(n=32)$ dan Kelas VIII-F $(n=33)$ sebagai sampel penelitian. One sample t-test digunakan untuk menguji keefektifan model CORE dengan strategi konflik kognitif dan model konvensional, sedangkan untuk menguji perbedaan keefektifan model pembelajaran digunakan uji Manova (Hotelling's Trace). Hasil penelitian menunjukkan bahwa: (1) model pembelajaran CORE dengan strategi konflik kognitif efektif ditinjau dari prestasi belajar, kemampuan berpikir kritis, dan self-efficacy siswa; (2) model pembelajaran CORE dengan strategi konflik kognitif lebih efektif dibandingkan model konvensional ditinjau dari prestasi belajar, kemampuan berpikir kritis, dan self-efficacy siswa.

The study aimed to examine the effectiveness of Connecting, Organizing, Reflecting, Extending (CORE) learning model with cognitive conflict strategies in terms of students' achievement, critical thinking, and self-efficacy. The study was a quasi-experiment with a pretest-posttest nonequivalent group design. The population of the study was all students of 8th-grade of SMP Negeri 3 Yogyakarta (Junior High School), Indonesia, and randomly selected class VIII-C $(n=32)$ and class VIII- $F(n=33)$ as the sample. One sample t-test was used to examine the effectiveness of the CORE learning model with cognitive conflict strategies and the conventional model. Whereas, to examine the difference between the effectiveness of the learning model, the Manova test (Hotelling's Trace) was used. The result of the study showed that: (1) the CORE learning model with cognitive conflict strategies was effective in terms of students' learning achievement, critical thinking skill, and self-efficacy; (2) The CORE learning model with cognitive conflict strategies was more effective than the conventional model in terms of students' learning achievement, critical thinking skills, and self-efficacy.

This is an open access article under the CC-BY-SA license

\section{How to Cite:}

Ningsih, S. W., Sugiman, S., Merliza, P., \& Ralmugiz, U. (2020). Keefektifan model pembelajaran CORE dengan strategi konflik kognitif ditinjau dari prestasi belajar, berpikir kritis, dan self-efficacy. Pythagoras: Jurnal Pendidikan Matematika, 15(1), $73-86$. https://doi.org/10.21831/pg.v15i1.34614

https://doi.org/10.21831/pg.v15i1.34614

\section{PENDAHULUAN}

Indonesia sebagai negara berkembang memiliki tantangan tersendiri seiring tuntutan zaman yang semakin tinggi. Era globalisasi dan teknologi yang semakin meningkat pesat membuat Indonesia harus banyak berbenah agar dapat menghasilkan sumber daya manusia yang berkualitas. Sumber daya manusia yang berkualitas dapat dihasilkan lewat pendidikan yang bermutu. Oleh karena itu pendidikan menjadi fokus utama untuk dapat memperbaiki kualitas sumber daya manusia. 
Melihat kebutuhan tersebut, maka pendidikan di Indonesia telah melakukan pembenahan-pembenahan di berbagai sektor pendidikan, mulai dari sistem pendidikan dan struktur pendidikan di Indonesia. Kurikulum yang berlaku di Indonesia telah mengalami 11 kali perubahan terhitung sejak Indonesia merdeka. Perubahan tersebut dimaksudkan untuk terus memperbaiki sistem pendidikan dan menghasilkan pendidikan yang berkualitas. Perbaikan dalam sistem penilaian juga telah dilakukan pemerintah dengan tidak menjadikan nilai ujian nasional (UN) sebagai satu-satunya penentu kelulusan siswa di tingkat sekolah dasar dan menengah. Meskipun demikian, nilai UN yang diperoleh dapat dijadikan sebagai parameter yang dapat menunjukkan ketercapaian nilai mata pelajaran yang diujikan pada jenjang sekolah dasar dan menengah, termasuk mata pelajaran matematika.

Sebagai salah satu mata pelajaran yang diberikan pada tingkat sekolah, Matematika sebaiknya menjadi perhatian sebab sangat penting untuk dapat menghasilkan sumber daya manusia yang bermutu. Hal ini disebutkan dalam Permendikbud Nomor 58 Tahun 2014, bahwa matematika merupakan ilmu universal yang berguna bagi kehidupan manusia dan juga mendasari perkembangan teknologi modern, serta mempunyai peran penting dalam berbagai disiplin ilmu dan memajukan daya pikir manusia (Kemendikbud, 2014a). Lebih lanjut juga disebutkan bahwa Matematika adalah kunci ke arah peluang-peluang. Bagi seorang siswa keberhasilan mempelajarinya akan membuka pintu karier yang cemerlang. Bagi para warga negara, matematika akan menunjang pengambilan keputusan yang tepat.

Pembelajaran matematika hendaknya dinilai secara komprehensif sebagaimana disebutkan dalam Permendikbud Nomor 104 Tahun 2014 bahwa penilaian hasil belajar peserta didik mencakup kompetensi sikap, pengetahuan, dan keterampilan yang dilakukan secara berimbang sehingga dapat digunakan untuk menentukan posisi relatif setiap peserta didik terhadap standar yang telah ditetapkan (Kemendikbud, 2014b). Proses pembelajaran sepenuhnya diarahkan pada pengembangan ketiga ranah tersebut secara utuh/holistik, artinya pengembangan ranah yang satu tidak bisa dipisahkan dengan ranah lainnya. Dengan demikian proses pembelajaran secara utuh melahirkan kualitas pribadi yaitu sikap, pengetahuan, dan keterampilan.

Aspek pengetahuan secara umum dapat dilihat dari bagaimana prestasi siswa yang dicapai dalam pembelajaran matematika. Prestasi belajar matematika dapat menunjukkan pemahaman siswa pada materi yang diajarkan. Black-Hawkins et al. (2007, p.22) menyatakan bahwa disisi lain prestasi berkaitan dengan kemajuan peserta didik dari waktu ke waktu. Hal ini bermakna bahwa prestasi dapat didefinisikan sebagai kemajuan yang dibuat oleh siswa selama periode waktu tertentu. Sehingga kemajuan yang dicapai siswa dalam belajar merupakan suatu proses yang membutuhkan waktu.

Secara umum, prestasi belajar matematika siswa di Indonesia dapat dilihat pada pencapaian nilai Ujian Nasional (UN). Berdasarkan laporan hasil UN tahun ajaran 2015/2016 diperoleh rata-rata nasional nilai matematika masih belum mencapai angka yang memuaskan yaitu 50,24 . Prestasi belajar matematika yang dicapai oleh siswa erat kaitannya dengan kemampuan berpikir siswa. Salah satu kemampuan berpikir siswa adalah kemampuan berpikir kritis. Berpikir melibatkan manipulasi otak terhadap informasi seperti saat kita membentuk konsep. Berpikir kritis dalam matematika sangat erat kaitannya jika siswa dihadapkan pada suatu masalah. John Dewey (Fisher, 2011), mengungkapkan berpikir kritis sebagai cara berpikir secara mendalam yang tidak begitu saja menerima informasi yang ada. Dalam berpikir kritis, seseorang berpikir lebih mendalam tentang masalah-masalah yang ada, melakukan penalaran logis, dan berupaya memeriksa keyakinan dan pengetahuan berdasarkan bukti. Lebih lanjut, Ennis (Fisher, 2011) menambahkan pengambilan keputusan sebagai bagian dari berpikir kritis. Menurut Ennis, berpikir kritis adalah pemikiran yang masuk akal dan reflektif yang berfokus untuk memutuskan apa yang harus dipercaya dan yang harus dilakukan.

Berpikir kritis penting dimiliki oleh siswa, seperti yang disebutkan oleh Ruggiero (2012), bahwa berpikir kritis merupakan salah satu subjek yang paling penting di sekolah terlepas dari kegiatan akademis. Hal ini sejalan dengan tujuan pembelajaran matematika yang disebutkan dalam Permendiknas Nomor 22 Tahun 2006 yaitu untuk mempersiapkan siswa agar sanggup menghadapi perubahan keadaan di dalam kehidupan dan di dunia yang selalu berkembang, melalui latihan bertindak atas dasar pemikiran secara logis, rasional, kritis, cermat, jujur, efisien dan efektif (Kemendiknas, 2006a). Selain hal tersebut, pentingnya berpikir kritis juga dipertegas dalam lampiran Permendiknas Nomor 23 Tahun 2006 tentang Standar Kompetensi Lulusan sekolah menengah yang menyatakan bahwa salah satu kompetensi yang harus dimiliki oleh peserta didik adalah dapat membangun dan menerapkan informasi dan pengetahuan secara logis, kritis, kreatif, dan inovatif; serta menunjukkan kemampuan berpikir logis, kritis, kreatif, dan inovatif dalam pengambilan keputusan (Kemendiknas, 2006b). Berpikir kritis dalam matematika 
juga penting sebab berpikir kritis dapat menjadi cara yang efektif untuk meningkatkan pemahaman tentang konsep-konsep matematika (Chukwuyenum, 2013).

Pada kenyataannya, kemampuan berpikir kritis siswa di Indonesia belum mampu dikembangkan secara optimal. Penerapan proses belajar mengajar di Indonesia kurang mendorong pada pencapaian kemampuan berpikir kritis. Seperti yang diungkapkan Santrock (2011, p.357), bahwa menurut para ahli pendidikan, hanya sedikit sekolah yang benar-benar mengajarkan siswanya untuk mengembangkan kemampuan berpikir kritis. Biasanya sekolah menghabiskan waktu untuk mengajar siswa dengan memberikan satu jawaban yang benar, sehingga kegiatan pembelajaran di kelas kurang mendorong siswa untuk memperluas pemikiran mereka dengan menciptakan ide-ide baru yang sesuai dengan kemampuan siswa. Proses pembelajaran di dalam kelas diarahkan kepada kemampuan siswa untuk menghafal informasi. Padahal keterampilan berpikir kritis merupakan salah satu modal dasar atau modal intelektual yang sangat penting bagi setiap orang dan merupakan bagian yang fundamental dari kematangan manusia. Oleh karena itu pengembangan keterampilan berpikir kritis menjadi sangat penting bagi siswa di setiap jenjang pendidikan.

Prestasi belajar siswa juga dapat dipengaruhi oleh aspek afektif siswa, seperti self-efficacy. Seperti pada hasil penelitian Ahmad (2016) menunjukkan bahwa self-efficacy, adversity quotient, dan motivasi berprestasi memiliki pengaruh tidak langsung terhadap prestasi belajar matematika siswa. Demikian pula penelitian yang dilakukan Rosyida et al. (2016) yang menunjukkan bahwa self-efficacy secara signifikan berpengaruh terhadap hasil belajar siswa. Self-efficacy merupakan keyakinan diri siswa akan kemampuannya dalam menyelesaikan masalah, menyelesaikan tugas tanpa membandingkan dengan kemampuan orang lain sehingga dapat mencapai keberhasilan dalam prestasi belajar matematika disertai dengan rasa yakin terhadap usaha yang dilakukan, pilihan yang ditentukan, dan memiliki ketekunan. Temuan lain berkaitan dengan self-efficacy adalah hasil penelitian Sewell dan George (2000) yang menemukan bahwa siswa dengan kelompok self-efficacy rendah merasa dirinya tidak berguna ketika berada di luar kelas, mereka juga mudah terganggu dan kurang termotivasi dalam kelas serta tidak bertahan ketika mereka mengalami kesulitan. Dari temuan tersebut, dapat dikatakan bahwa kelompok siswa dengan selfefficacy yang rendah memiliki masalah dari dalam diri mereka terkait keyakinan atas kemampuan yang dimiliki, serta tidak dapat bertahan dalam menghadapi kesulitan, khususnya ketika mendapat tugas yang sulit.

Sebaliknya, Betz dan Hacket (Pajares, 2002, p.11) mengatakan bahwa dengan self-efficacy yang tinggi pada umumnya seorang siswa akan lebih mudah dan berhasil melampaui latihan-latihan matematika yang diberikan kepadanya, sehingga hasil akhir dari pembelajaran tersebut yang tercermin dalam prestasi akademiknya juga cenderung akan lebih tinggi dibandingkan siswa yang memiliki self-efficacy rendah. Selain itu, self-efficacy juga dapat membuat seseorang lebih mudah dan lebih merasa mampu untuk mengerjakan soal-soal matematika yang dihadapinya, bahkan soal matematika yang lebih rumit atau spesifik sekalipun hingga berkaitan dengan prestasi matematika siswa (Santrock, 2011). Hal ini menunjukkan pentingnya self-efficacy bagi siswa.

Prestasi belajar siswa, kemampuan berpikir kritis dan self-efficacy siswa saling mendukung pencapaian prestasi belajar matematika siswa. Dengan memiliki kemampuan berpikir kritis yang baik, prestasi belajar siswa juga dapat menjadi lebih baik. Lebih lanjut, temuan Dehghani et al. (2011) juga menunjukkan hubungan positif signifikan antara self-efficacy siswa dan berpikir kritis. Oleh karena itu, self-efficacy sebagai faktor motivasi (Pajares, 2005) harus dipertimbangkan untuk mengembangkan keterampilan berpikir kritis peserta didik. Self-efficacy matematika sendiri merupakan skala untuk menilai, dengan tingkat yang lebih spesifik, yang berhubungan dengan sekumpulan kepercayaan siswa untuk memecahkan masalah matematika (Zimmerman et al., 1996), menyelesaikan serangkaian tugas matematika dan berhasil dalam mata pelajaran matematika (Ayda \& Widjajanti, 2014; Langenfeld \& Pajares,1993).

Pentingnya aspek pengetahuan, keterampilan, dan sikap seperti yang telah dipaparkan tersebut hendaknya dapat terfasilitasi lewat pembelajaran matematika yang berlangsung di kelas. Untuk mendukung hal tersebut diperlukan inovasi dalam metode pembelajaran yang diberikan guru. Inovasi-inovasi dalam bidang pendidikan telah banyak dilakukan, khususnya dalam matematika. Telah banyak model pembelajaran yang berkembang dan diadaptasi oleh guru. Namun model pembelajaran yang telah ada pasti tidak dapat disamaratakan dengan semua sekolah, semua daerah, dan semua materi, sehingga sangat perlu untuk mencari model pembelajaran yang dapat sesuai dengan kebutuhan siswa di suatu sekolah.

Permendikbud Nomor 22 Tahun 2016 tentang standar proses pendidikan dasar menengah mengungkapkan bahwa prinsip pembelajaran di antaranya adalah dari peserta didik diberi tahu menuju peserta didik mencari tahu serta dari guru sebagai satu-satunya sumber belajar menjadi belajar berbasis aneka sumber belajar (Kemendikbud, 
2016). Salah satu model pembelajaran yang dapat dijadikan sebagai salah satu alternatif adalah model CORE (Connecting, Organizing, Reflecting, Extending). Model CORE memberikan kesempatan bagi siswa untuk dapat menghubungkan dan mengorganisasikan pengetahuan siswa yang telah ada (Curwen et al., 2010; Dymock, 2005; Miller \& Calfee, 2004). Model pembelajaran CORE merupakan model pembelajaran yang berbasis konstruktivisme yaitu berpusat pada siswa yang menyediakan pembelajaran yang dapat mengaktifkan aktivitas siswa, sehingga pembelajaran matematika lebih efektif, seperti halnya pembelajaran berbasis penemuan (Miller \& Calfee, 2004). Dengan model pembelajaran CORE diharapkan dapat meningkatkan prestasi belajar matematika, kemampuan berpikir kritis, dan self-efficacy siswa.

Pada tahap Connecting, guru mengaktifkan pengetahuan siswa sebelumnya dengan cara siswa merefleksikan apa yang telah diketahuinya, berdiskusi dengan siswa lain, atau menulis pengetahuan dan pengalaman mereka yang berkaitan dengan topik yang akan dipelajari (Curwen etal., 2010). Pada tahap Organizing, guru menggunakan diskusi kelas untuk mengecek pengetahuan siswa sebelumnya (Miller \& Calfee, 2004). Pada tahap ini, strategi yang digunakan guru sangat penting agar mendapatkan penguatan atas pengetahuan atau konsep yang telah dimiliki siswa untuk diberikan suatu topik baru. Selanjutnya pada tahap Reflecting siswa memikirkan secara mendalam konsep yang dipelajarinya (Miller \& Calfee, 2004). Siswa mengendapkan apa yang baru dipelajarinya sebagai struktur pengetahuan yang baru, yang merupakan pengayaan atau revisi dari pengetahuan sebelumnya. Pada tahap ini siswa dapat melatih kemampuan berpikir kritisnya sebelum menentukan keputusan atau strategi yang akan dipilih untuk dapat menyelesaikan tugas/permasalahan matematika yang diberikan. Selanjutnya pada tahap Extending, yaitu tahap siswa memperluas pengetahuan (Suyatno, 2009) yang mereka peroleh selama proses belajar mengajar berlangsung dengan cara mengomunikasikan gagasannya dan mendengarkan pendapat dari yang lain. Pada tahap ini siswa mendapat penguatan dari guru agar siswa dapat dengan yakin menyampaikan gagasannya sehingga self-efficacy siswa diharapkan dapat diasah pada tahap ini.

Chambliss dan Calfee (Curwen et al., 2010) mengemukakan bahwa Model pembelajaran CORE juga memperhatikan struktur kognitif siswa sebab terdapat fase Connecting yang menuntut siswa untuk mengatur struktur kognitifyang dimiliki. Oleh karena itu, selain model pembelajaran CORE, strategi konflik kognitif perlu diintegrasikan bersama dengan model pembelajaran CORE. Konflik kognitif adalah keadaan persepsi yang berbeda antara struktur kognitif seseorang dengan lingkungan (informasi eksternal), atau antara komponen yang berbeda (misalnya, konsepsi, keyakinan, sub-struktur dan sebagainya) dari struktur kognitif seseorang (Lee \& Kwon, 2001). Lee et al. (2003) menjelaskan tiga tahapan pembelajaran yang melibatkan fase berpikir yang terdiri dari fase permulaan, fase konflik, dan fase penyelesaian. Faktanya, tahapan pembelajaran yang memanfaatkan strategi konflik kognitif berpengaruh positif pada kemampuan berpikir kritis dan sikap peserta didik (Ismaimuza, 2010). Dengan demikian, mengintegrasikan strategi konflik kognitif dalam model pembelajaran CORE diharapkan dapat menjadi stimulus untuk kemampuan berpikir kritis siswa, serta lebih meyakinkan siswa akan keputusan serta pengetahuan yang diperolehnya dalam pembelajaran.

Berdasarkan penelitian-penelitian yang telah dilakukan, model pembelajaran CORE dapat meningkatkan kemampuan matematis siswa. Penelitian Kumalasari (2011) yang menemukan bahwa peningkatan kemampuan pemecahan masalah matematis siswa yang belajar dengan model CORE lebih baik daripada siswa yang belajar melalui pembelajaran konvensional. Demikian juga dengan temuan Tamalene (2010) yang menunjukkan bahwa kemampuan penalaran matematis siswa yang memperoleh pembelajaran dengan model CORE melalui pendekatan keterampilan kognitif lebih baik daripada siswa yang memperoleh pembelajaran konvensional. Penelitian Ramadhani dan Kusuma (2020, p.54) menemukan bahwa pembelajaran CORE dapat meningkatkan kemampuan koneksi dan self-efficacy siswa. Yaniawati et al. (2019) mengungkapkan bahwa pembelajaran yang melibatkan model CORE dapat meningkatkan komunikasi dan koneksi matematis siswa dibandingkan pembelajaran ekspositori. Selain itu, faktanya model CORE dengan strategi konflik kognitif dapat meningkatkan kemampuan berpikir kritis dan prestasi belajar siswa (Darojah, 2018), serta pemecahan masalah dan kecemasan (Susilowaty \& Marpaung, 2018), serta menunjukkan pemahaman matematis, kemampuan pemecahan masalah, dan habits of mind siswa lebih baik (Humaira, 2015).

Beberapa penelitian yang telah meneliti tentang model pembelajaran CORE serta model pembelajaran CORE dengan strategi konflik kognitif masih terbatas dalam meneliti tentang bagaimana keefektifan penerapan model pembelajaran ini jika ditelaah dari aspek prestasi, kemampuan berpikir kritis, dan self-efficacy siswa. Oleh karena itu, peneliti tertarik untuk mengkaji lebih dalam penerapan model pembelajaran CORE dengan strategi konflik kognitif ditinjau dari ketiga aspek tersebut, baik secara bersama-sama maupun secara parsial di sekolah yang memiliki 
daya serap materi geometri serta dengan karakteristik memiliki letak strategis di tengah kota dan memiliki prestasi belajar matematika yang masih rendah. Berdasarkan uraian sebelumnya, diduga model pembelajaran CORE dengan strategi konflik kognitif efektif jika ditinjau dari prestasi belajar matematika, kemampuan berpikir kritis, dan self-efficacy siswa, sehingga peneliti bermaksud untuk melakukan penelitian untuk menguji keefektifan model pembelajaran CORE dengan strategi konflik kognitif ditinjau dari prestasi belajar, kemampuan berpikir kritis, dan self-efficacy siswa.

\section{METODE}

Jenis penelitian ini adalah eksperimen semu (quasi experiment) dengan pretest-posttest nonequivalent control group design. Penelitian ini dilaksanakan di SMP Negeri 3 Yogyakarta pada semester genap tahun ajaran 2016/ 2017. Populasi penelitian adalah seluruh siswa kelas VIII Tahun Ajaran 2016/2017 di SMP Negeri 3 Yogyakarta. Sampel penelitian diperoleh dengan cara acak (simple random sampling), sehingga diperoleh kelas VIII-F sebagai kelas eksperimen yang diberi perlakuan model pembelajaran CORE dengan strategi konflik kognitif (CORE-KK) dan kelas VIII-C sebagai kelas kontrol yang diberi perlakuan model pembelajaran konvensional yaitu pembelajaran langsung. Kelas VIII-F berjumlah 33 siswa yang terdiri dari 13 laki-laki dan 20 perempuan, kelas VIII-C berjumlah 32 siswa yang terdiri dari 17 laki-laki dan 15 perempuan. Sampel yang dipilih memiliki kisaran usia 13-14 tahun. Variabel bebas dalam penelitian ini berupa model pembelajaran dan variabel terikat adalah prestasi belajar matematika, kemampuan berpikir kritis, dan self-efficacy siswa.

\section{Instrumen Pengumpulan Data}

Instrumen yang digunakan dalam penelitian ini terdiri atas instrumen tes dan non tes. Instrumen tes terdiri dari tes prestasi belajar sebanyak 25 butir soal pilihan ganda dan tes kemampuan berpikir kritis sebanyak 4 butir soal essay yang mencakup indikator interpretation, analysis, evaluation, dan inference. Tes prestasi belajar dan berpikir kritis mengacu pada standar kompetensi Kurikulum Tingkat Satuan Pendidikan (KTSP) materi bangun ruang sisi datar. Instrumen non tes terdiri atas angket self-efficacy sebanyak 12 butir pernyataan positif dan 12 butir pernyataan negatif. Angket self-efficacy disusun dengan menggunakan skala Likert yaitu selalu (SL), sering (SR), kadang-kadang (KK), jarang (JR), dan tidak pernah (TP). Skor untuk masing-masing pernyataan secara berturut-turut yaitu 5, 4, 3, 2, 1 untuk pernyataan positif dan 1, 2, 3, 4, 5 untuk pernyataan negatif. Instrumen-instrumen tersebut diberikan kepada siswa kelas CORE-KK dan konvensional baik sebelum perlakuan (pretest) maupun sesudah perlakuan (posttest). Instrumen pretest dan posttest diberikan dengan tujuan untuk mengetahui prestasi belajar matematika, kemampuan berpikir kritis, dan self-efficacy siswa sebelum dan sesudah diberi perlakuan.

\section{Validitas dan Reliabilitas Instrumen}

Validitas yang digunakan pada instrumen yang mengukur prestasi belajar matematika, kemampuan berpikir kritis, dan self-efficacy siswa yaitu validitas isi yang terdiri atas validitas logis dan validitas muka. Bukti validitas isi pada instrumen penelitian ini diberikan oleh dua validator ahli yang merupakan dosen Pascasarjana Universitas Negeri Yogyakarta. Setelah memperoleh bukti validitas isi dari pertimbangan para ahli yang menyatakan bahwa instrumen sudah siap digunakan dalam penelitian, instrumen di uji cobakan untuk mengestimasi reliabilitasnya. Hasil estimasi reliabilitas disajikan pada Tabel 1.

Tabel 1. Hasil estimasi reliabilitas instrumen penelitian

\begin{tabular}{lcc}
\hline \multirow{2}{*}{ Instrumen } & \multicolumn{2}{c}{ Koefisien Reliabilitas } \\
\cline { 2 - 3 } & Pretest & Posttest \\
\hline Tes prestasi belajar matematika & 0,668 & 0,731 \\
Tes kemampuan berpikir kritis & 0,702 & 0,676 \\
Angket self-efficacy siswa & \multicolumn{2}{c}{0,934} \\
\hline
\end{tabular}

Berdasarkan Tabel 1 dapat dilihat bahwa koefisien reliabilitas semua instrumen lebih dari 0,65 sehingga dapat disimpulkan bahwa semua instrumen penelitian reliabel.

\section{Teknik Analisis Data}

Data penelitian yang dianalisis adalah data pretest dan posttest prestasi belajar matematika, kemampuan berpikir kritis, dan self-efficacy siswa. Data pretest digunakan untuk mengetahui kondisi awal kedua kelas sampel, 
sedangkan data posttest digunakan untuk menguji dan membandingkan keefektifan model pembelajaran COREKK dan model konvensional. Data tersebut dianalisis dengan dua cara yaitu analisis deskriptif dan analisis inferensial.

Analisis data deskriptif digunakan untuk mendeskripsikan data prestasi belajar matematika, kemampuan berpikir kritis, dan self-efficacy siswa sebelum dan sesudah perlakuan. Data yang disajikan terdiri atas rata-rata (mean), standar deviasi (SD), nilai maksimum dan minimum yang dicapai, serta persentase ketuntasan siswa. Data nilai prestasi belajar matematika, kemampuan berpikir kritis, serta self-efficacy siswa dideskripsikan dengan cara membandingkan skor rata-rata setiap variabel dengan kriteria ketuntasan minimal yang ditetapkan. Kriteria ketuntasan untuk masing-masing variabel yaitu rata-rata nilai kemampuan berpikir kritis dan prestasi belajar siswa minimal 70, dan self-efficacy siswa sebesar 81,6 (tinggi).

Data self-efficacy siswa yang diperoleh dikategorisasikan berdasarkan kriteria yang digunakan. Kategorisasi yang digunakan diadaptasi dari Widoyoko (2015), sehingga dalam penelitian ini diperoleh interval skor dan kategori self-efficacy seperti pada Tabel 2.

Tabel 2. Kriteria self-efficacy matematika siswa

\begin{tabular}{cl}
\hline Interval & Kategori \\
\hline $100,8<X \leq 120$ & Sangat Tinggi \\
$81,6<X \leq 100,8$ & Tinggi \\
$62,4<X \leq 81,6$ & Sedang \\
$43,2<X \leq 62,4$ & Rendah \\
$X \leq 43,2$ & Sangat Rendah \\
\hline
\end{tabular}

Data self-efficacy siswa yang telah diperoleh dikategorisasikan berdasarkan kriteria pada Tabel 2. Dari hasil tersebut kemudian diperoleh persentase untuk masing-masing kategori.

Analisis data inferensial digunakan untuk membuktikan secara statistik hipotesis penelitian yang diajukan serta menjawab rumusan masalah yang ditetapkan. Untuk menguji keefektifan model pembelajaran secara parsial ditinjau dari prestasi belajar matematika, kemampuan berpikir kritis, dan self-efficacy siswa digunakan uji one sample t test. Selanjutnya untuk menguji perbedaan keefektifan model pembelajaran secara simultan ditinjau dari prestasi belajar matematika, kemampuan berpikir kritis, dan self-efficacy siswa digunakan uji Hotelling's $T^{2}$ (analisis multivariat). Jika hasil uji Hotelling's $T^{2}$ menolak $\mathrm{H}_{0}$ maka pengujian dilanjutkan untuk menyelidiki variabel mana yang berbeda signifikan menggunakan independet sample $t$ test. Semua pengujian statistik menggunakan taraf signifikansi $\alpha=0,05$.

Sebelum dilakukan uji hipotesis, terlebih dahulu dilakukan uji asumsi. Uji asumsi yang dilakukan adalah uji normalitas dan homogenitas univariat dan multivariat. Uji normalitas univariat dilakukan menggunakan uji Kolmogrov-smirnov, sedangkan normalitas multivariat menggunakan jarak Mahalanobis $\left(d_{i}^{2}\right)$. Kriteria yang digunakan apabila sekitar $50 \%$ nilai $d_{i}^{2}<\chi_{p, 0.5}^{2}$ maka data tersebut berdistribusi normal multivariat (Johnson \& Winchern, 2007). Uji homogenitas menggunakan uji Levene, sedangkan uji homogenitas multivariat dengan menggunakan uji Box's M (Stevens, 2009).

\section{HASIL PENELITIAN}

\section{Deskripsi Hasil Penelitian}

Analisis data deskriptif dilakukan pada data sebelum (pretest) dan sesudah perlakuan (posttest). Data pretest dan posttest berupa nilai prestasi belajar matematika, kemampuan berpikir kritis, dan self-efficacy siswa. Data pretest dan posttest tersebut digunakan untuk menguji keefektifan model pembelajaran CORE-KK dan model pembelajaran konvensional ditinjau dari prestasi belajar matematika, kemampuan berpikir kritis, dan self-efficacy siswa. Deskripsi hasil tes prestasi belajar matematika, kemampuan berpikir kritis, dan self-efficacy siswa pada pretest maupun posttest untuk kedua kelas secara berturut-turut disajikan pada Tabel 3, Tabel 4, dan Tabel 5.

Tabel 3 menunjukkan bahwa nilai rata-rata pretest prestasi belajar matematika pada kelas CORE-KK yaitu 33,94 mengalami peningkatan sebesar 43,39 poin menjadi 77,33 pada posttest. Sedangkan, nilai rata-rata pretest prestasi belajar matematika pada kelas konvensional yaitu 32,00 mengalami peningkatan sebesar 35,5 menjadi 67,50 pada posttest. Selain itu, berdasarkan persentase ketuntasan belajar, pada kelas CORE-KK diperoleh persentase ketuntasan sebesar $0 \%$ yang mencapai KKM pada pretest, namun meningkat menjadi 84,85\% (28 siswa) yang 
PYTHAGORAS: Jurnal Pendidikan Matematika, 15 (1), 2020 - 79

Sri Wahyuni Ningsih, Sugiman, Pika Merliza, Uke Ralmugiz

mencapai KKM pada posttest. Sedangkan, pada kelas konvensional diperoleh persentase ketuntasan sebesar $0 \%$ pada pretest meningkat menjadi 31,25\% (10 siswa) yang mencapai KKM pada posttest.

Tabel 3. Deskripsi hasil pretest dan posttest prestasi belajar matematika siswa

\begin{tabular}{lcccc}
\hline \multirow{2}{*}{ Deskripsi } & \multicolumn{2}{c}{ CORE-KK } & \multicolumn{2}{c}{ Konvensional } \\
\cline { 2 - 5 } & Pretest & Posttest & Pretest & Posttest \\
\hline Mean & 33,94 & 77,33 & 32,00 & 67,50 \\
Simpangan Baku & 7,56 & 9,42 & 6,58 & 8,84 \\
Variansi & 57,12 & 88,67 & 43,35 & 78,19 \\
Nilai Maksimum & 52 & 96 & 60 & 84 \\
Nilai Minimum & 16 & 60 & 28 & 48 \\
Persentase Ketuntasan & $0 \%$ & $84,85 \%$ & $0 \%$ & $31,25 \%$ \\
\hline
\end{tabular}

Tabel 4. Deskripsi hasil pretest dan posttest kemampuan berpikir kritis matematika siswa

\begin{tabular}{lcccc}
\hline \multirow{2}{*}{ Deskripsi } & \multicolumn{2}{c}{ CORE-KK } & \multicolumn{2}{c}{ Konvensional } \\
\cline { 2 - 5 } & Pretest & Posttest & Pretest & Posttest \\
\hline Mean & 15,85 & 78,09 & 18,27 & 32,69 \\
Simpangan Baku & 7,91 & 8,41 & 11,84 & 21,93 \\
Variansi & 62,65 & 70,71 & 140,29 & 481,01 \\
Nilai Maksimum & 38,46 & 92,31 & 53,85 & 76,92 \\
Nilai Minimum & 7,69 & 61,54 & 0 & 7,69 \\
Persentase Ketuntasan & $0 \%$ & $78,79 \%$ & $0 \%$ & $12,5 \%$ \\
\hline
\end{tabular}

Tabel 4 menunjukkan bahwa nilai rata-rata kemampuan berpikir kritis matematika pada kelas CORE-KK dan kelas konvensional mengalami peningkatan dari pretest ke posttest. Nilai rata-rata pretest kemampuan berpikir kritis matematika pada kelas CORE-KK sebesar 15,85 pada pretest mengalami peningkatan menjadi 78,09 pada posttest, dengan persentase ketuntasan sebesar $0 \%$ pada pretest meningkat menjadi $78,79 \%$ ( 26 siswa) pada posttest. Sedangkan, nilai rata-rata pretest kemampuan berpikir kritis matematika pada kelas konvensional sebesar 18,27 pada pretest mengalami peningkatan menjadi 32,69 pada posttest, dengan persentase ketuntasan sebesar $0 \%$ pada pretest meningkat menjadi $12,5 \%$ ( 4 siswa) pada posttest.

Tabel 5. Deskripsi hasil pretest dan posttest self-efficacy matematika siswa

\begin{tabular}{lcccc}
\hline \multirow{2}{*}{ Deskripsi } & \multicolumn{2}{c}{ CORE-KK } & \multicolumn{2}{c}{ Konvensional } \\
\cline { 2 - 5 } & Pretest & Posttest & Pretest & Posttest \\
\hline Mean & 80,70 & 85,94 & 76,03 & 77,19 \\
Simpangan Baku & 9,31 & 9,94 & 9,22 & 10,13 \\
Variansi & 86,66 & 98,91 & 85,06 & 102,67 \\
Nilai Maksimum & 100 & 107 & 98 & 97 \\
Nilai Minimum & 65 & 63 & 60 & 61 \\
\hline
\end{tabular}

Tabel 5 menunjukkan bahwa nilai rata-rata self-efficacy siswa pada kelas CORE-KK dan kelas konvensional sebelum perlakuan (pretest) relatif sama. Namun, setelah diberi perlakuan (posttest) nilai rata-rata self-efficacy siswa pada kedua kelas tersebut mengalami peningkatan. Nilai rata-rata pretest self-efficacy siswa pada kelas COREKK sebesar 80,70 mengalami peningkatan menjadi 85,94 pada posttest. Sedangkan, nilai rata-rata pretest selfefficacy siswa pada kelas konvensional sebesar 76,03 mengalami peningkatan menjadi 77,19 pada posttest.

Selanjutnya kategorisasi self-efficacy siswa pada kelas CORE-KK dan kelas konvensional disajikan pada Tabel 6. Pada kelas CORE-KK, jumlah siswa dengan self-efficacy berada pada kategori tinggi dan sangat tinggi mengalami peningkatan, sedangkan untuk siswa dengan self-efficacy berada pada kategori sedang mengalami penurunan. Hasil yang sedikit berbeda terjadi pada kelas konvensional, dimana jumlah siswa dengan self-efficacy pada kategori sangat tinggi tidak mengalami peningkatan, meskipun jumlah siswa dengan self-efficacy pada kategori tinggi mengalami peningkatan. 
Tabel 6. Kategorisasi self-efficacy siswa pada kelas Core-KK dan kelas konvensional

\begin{tabular}{clcccc}
\hline \multirow{2}{*}{ Interval } & \multirow{2}{*}{ Kategori } & $\begin{array}{c}\text { CORE-KK } \\
\text { Pretest }\end{array}$ & $\begin{array}{c}\text { CORE-KK } \\
\text { Posttest }\end{array}$ & $\begin{array}{c}\text { Konvensional } \\
\text { Pretest }\end{array}$ & $\begin{array}{c}\text { Konvensional } \\
\text { Postest }\end{array}$ \\
\cline { 3 - 6 } & & $f(\%)$ & $f(\%)$ & $f(\%)$ & $f(\%)$ \\
\hline $100,8<X \leq 120$ & Sangat Tinggi & $2(6,07)$ & $8(24,24)$ & $1(3,12)$ & $1(3,12)$ \\
$81,6<X \leq 100,8$ & Tinggi & $16(48,48)$ & $20(60,61)$ & $9(28,13)$ & $17(53,13)$ \\
$62,4<X \leq 81,6$ & Sedang & $15(45,45)$ & $5(15,15)$ & $22(68,75)$ & $14(43,75)$ \\
$43,2<X \leq 62,4$ & Rendah & 0 & 0 & 0 & 0 \\
$X \leq 43,2$ & Sangat Rendah & 0 & 0 & 0 & 0 \\
\hline
\end{tabular}

Kesamaan Vektor Rerata Sebelum Perlakuan

Uji kesamaan vektor rata-rata sebelum perlakuan dilakukan untuk menguji apakah vektor rata-rata kedua kelas (CORE-KK vs. Konvensional) ditinjau dari kemampuan berpikir kritis, prestasi belajar, dan self-efficacy matematika siswa adalah sama. Namun, sebelum itu dilakukan uji asumsi normalitas dan homogenitas. Uji normalitas dilakukan pada skor data pretest prestasi belajar matematika, kemampuan berpikir kritis, dan self-efficacy siswa yang telah diperoleh. Hasil uji normalitas multivariat dengan menggunakan uji jarak Mahalanobis disajikan pada Tabel 7.

Tabel 7. Hasil uji normalitas multivariat pretest

\begin{tabular}{lcc}
\hline Kelas & $d^{2}<\chi_{0,5(3)}^{2}$ & Keterangan \\
\hline CORE-KK & $54,55 \%$ & Normal \\
Konvensional & $53,13 \%$ & Normal \\
\hline
\end{tabular}

Tabel 7 menunjukkan bahwa nilai jarak Mahalanobis yang kurang dari nilai chi-square tabel untuk kelas COREKK dan konvensional secara berturut-turut yaitu sebesar 54,55\% dan 53,13\% yang memiliki nilai kurang dari $\chi_{0,5(3)}^{2}=2,366$. Dengan demikian, dapat disimpulkan bahwa data pretest prestasi belajar matematika, kemampuan berpikir kritis, dan self-efficacy siswa berdistribusi normal multivariat. Berdasarkan hasil uji homogenitas data pretest diperoleh nilai Box's $M=7,897, F=1,248, p=0,278$. Dari hasil tersebut dapat disimpulkan bahwa matriks varians-kovarians pada kelas CORE-KK dan konvensional sebelum diberikan perlakuan adalah homogen.

Hasil uji kesamaan vektor rata-rata kedua kelas memperoleh $F(3,61)=2,061, p=0,101$, Hotelling's Trace = 0,101 . Hasil tersebut menunjukkan bahwa $\mathrm{H}_{0}$ diterima, sehingga dapat disimpulkan bahwa tidak terdapat perbedaan skor rata-rata pretest prestasi belajar matematika, kemampuan berpikir kritis, dan self-efficacy siswa pada kedua kelas, dengan kata lain kemampuan siswa pada kedua kelas sebelum diberi perlakuan adalah sama.

\section{Efektivitas Model CORE-KK}

Uji one sample t test digunakan untuk menguji efektivitas model CORE-KK secara parsial ditinjau dari prestasi belajar matematika, kemampuan berpikir kritis, dan self-efficacy siswa. Namun, terlebih dahulu dilakukan uji asumsi univariat terhadap data posttest kelas CORE-KK menggunakan uji Kolmogorov-Smirnov. Adapun hasilnya disajikan pada Tabel 8.

Tabel 8. Hasil uji normalitas univariat data posttest kelas CORE-KK

\begin{tabular}{lcc}
\hline Variabel & Nilai statistik & $p$ \\
\hline Prestasi Belajar Matematika & 0,839 & 0,482 \\
Kemampuan Berpikir Kritis & 1,336 & 0,056 \\
Self-efficacy & 0,629 & 0,824 \\
\hline
\end{tabular}

Hasil uji asumsi pada Tabel 8 menunjukkan bahwa data posttest kelas CORE-KK memiliki distribusi normal, sehingga pengujian keefektifan model pembelajaran untuk masing-masing variabel dapat dilakukan.

Hasil uji keefektifan model pembelajaran CORE-KK disajikan pada Tabel 9. Berdasarkan Tabel 9 terlihat bahwa model pembelajaran CORE-KK efektif ditinjau dari prestasi belajar matematika, $t(32)=4,535, p<0,05$, kemampuan berpikir kritis, $t(32)=5,593, p<0,05$, dan self-efficacy siswa, $t(32)=2,508, p<0,05$. 
PYTHAGORAS: Jurnal Pendidikan Matematika, 15 (1), 2020 - 81

Sri Wahyuni Ningsih, Sugiman, Pika Merliza, Uke Ralmugiz

Tabel 9. Hasil uji one sample t test kelas CORE-KK

\begin{tabular}{lccccc}
\hline Variabel & Test value & $t$ & $d f$ & $t$ tabel & Keputusan \\
\hline Prestasi Belajar Matematika & 70 & 4,535 & 32 & 2,0369 & Tolak $\mathrm{H}_{0}$ \\
Kemampuan Berpikir Kritis & 70 & 5,593 & 32 & 2,0369 & Tolak $\mathrm{H}_{0}$ \\
Self-efficacy & 81,6 & 2,508 & 32 & 2,0369 & Tolak $\mathrm{H}_{0}$ \\
\hline
\end{tabular}

Perbandingan Keefektifan Model Pembelajaran CORE-KK dan Konvensional

Uji perbedaan keefektifan model pembelajaran CORE-KK dan dilakukan dengan menggunakan uji Hotelling's $T^{2}$. Sebelum dilakukan pengujian hipotesis, terlebih dahulu dilakukan uji normalitas multivariat terhadap data posttest, baik pada kelas CORE-KK maupun kelas Konvensional. Adapun hasilnya disajikan pada Tabel 10.

Tabel 10. Hasil uji normalitas multivariat posttest

\begin{tabular}{lcc}
\hline Kelas & $d^{2}<\chi_{0,5(3)}^{2}$ & Keterangan \\
\hline CORE-KK & $45,45 \%$ & Normal \\
Konvensional & $43,75 \%$ & Normal \\
\hline
\end{tabular}

Tabel 10 menunjukkan bahwa nilai jarak Mahalanobis yang kurang dari nilai chi-square tabel untuk kelas CORE-KK dan konvensional secara berturut-turut yaitu sebesar $45,45 \%$ dan $43,75 \%$ yang memiliki nilai kurang dari $\chi_{0,5(3)}^{2}=$ 2,366 . Dengan demikian, dapat disimpulkan bahwa data posttest prestasi belajar matematika, kemampuan berpikir kritis, dan self-efficacy siswa berdistribusi normal multivariat.

Berdasarkan hasil uji homogenitas data posttest diperoleh nilai Box's $M=32,038, F=5,063, p<0,001$. Dari hasil tersebut dapat disimpulkan bahwa matriks varians-kovarians data pada kelas CORE-KK dan konvensional setelah diberikan perlakuan adalah tidak homogen. Namun hal ini tidakmenjadi masalah, karena sampel penelitian yang digunakan jumlahnya relatif kecil. Glass dan Hopkins (2008) menyatakan bahwa jika sampel dalam jumlah kecil dan matriks varians-kovarians tidak homogen, maka hal ini hanya akan memberikan pengaruh yang kecil terhadap hasil analisis.

Hasil uji perbedaan keefektifan model pembelajaran memperoleh $F(3,61)=58,175, p<0,001$, Hotelling's Trace $=2,861$. Dengan demikian, dapat disimpulkan bahwa prestasi belajar, kemampuan berpikir kritis, dan selfefficacy siswa pada kelas yang diajar dengan menerapkan model pembelajaran CORE-KK serta kelas yang diajar dengan model pembelajaran konvensional berbeda secara signifikan. Oleh karena itu, dilanjutkan pada uji perbandingan menggunakan uji independent $t$ test yang bertujuan untuk menyelidiki model pembelajaran mana yang lebih efektif. Hasil uji independent t test disajikan pada Tabel 11.

Tabel 11. Hasil uji perbandingan keefektifan model pembelajaran

\begin{tabular}{lccc}
\hline Variabel & $t(63)$ & $p$ & $\begin{array}{c}\text { Selisih Rerata } \\
\text { (CORE KK-Konvensional) }\end{array}$ \\
\hline Prestasi Belajar Matematika & 4,337 & 0,000 & 9,833 \\
Kemampuan Berpikir Kritis & 10,955 & 0,000 & 45,398 \\
Self-efficacy & 3,515 & 0,001 & 8,752 \\
\hline
\end{tabular}

Hasil pada Tabel 11 menunjukkan bahwa rerata prestasi belajar matematika siswa pada kelas CORE-KK dan kelas konvensional berbeda signifikan, $t(63)=4,337, p<0,001$. Karena rerata skor prestasi belajar matematika siswa pada kelas CORE-KK lebih tinggi daripada kelas konvensional (mean difference $=9,833$ ), maka dapat disimpulkan bahwa model pembelajaran CORE-KK lebih efektif dibandingkan model konvensional ditinjau dari prestasi belajar matematika siswa. Tabel 11 menunjukkan bahwa rerata kemampuan berpikir kritis siswa pada kelas COREKK dan kelas konvensional juga berbeda signifikan, $t(63)=10,955, p<0,001$. Karena rerata skor kemampuan berpikir kritis siswa pada kelas CORE-KK lebih tinggi daripada kelas konvensional (mean difference $=45,398$ ), maka dapat disimpulkan bahwa model pembelajaran CORE-KK lebih efektif dibandingkan model konvensional ditinjau dari kemampuan berpikir kritis siswa. Tabel 11 menunjukkan bahwa rerata self-efficacy siswa pada kelas CORE-KK dan kelas konvensional berbeda signifikan, $t(63)=3,515, p=0,001$. Karena rerata skor self-efficacy siswa pada kelas CORE-KK lebih tinggi daripada kelas konvensional (mean difference $=8,752$ ), maka dapat disimpulkan bahwa model pembelajaran CORE-KK lebih efektif dibandingkan model konvensional ditinjau dari self-efficacy siswa. 


\section{PEMBAHASAN}

Model pembelajaran CORE-KK efektif karena pada model pembelajaran CORE memanfaatkan pengetahuan siswa yang telah dimiliki sebelumnya terkait materi yang dipelajari. Hal tersebut ada pada tahap Connecting yang menuntut siswa untuk mampu menghubungkan pengetahuannya dengan pengetahuan baru yang diberikan. Lebih lanjut, siswa dilibatkan secara langsung dalam mengorganisir materi serta menemukan ide-ide setiap materi, sehingga diperoleh konsep baru pada tahap Organizing dan Reflecting. Apa yang diperoleh pada setiap tahap tersebut kemudian dilanjutkan dengan mendalami serta menerapkan apa yang telah diperoleh pada suatu permasalahan yang ada pada tahap Extending untuk bisa lebih memahami dari apa yang telah diperoleh, sehingga pengalaman belajar yang didapat lebih banyak. Langkah-langkah tersebut membantu siswa dalam menemukan ide-ide kunci, menyusun, menganalisis hingga menyelesaikan suatu permasalahan. Hal tersebut disajikan dalam Lembar Kerja Siswa (LKS) untuk model pembelajaran CORE.

Proses menghubungkan, menemukan, serta menerapkan konsep yang dipelajari melibatkan kemampuan prasyarat yang dimiliki siswa sehingga lebih memudahkan siswa dalam mengerjakan dan memahaminya. Rangkaian kegiatan dalam model pembelajaran CORE juga memperlihatkan bahwa siswa tidak hanya terlibat pada awal pembelajaran melainkan juga terlibat sampai akhir pembelajaran. Selain itu, penerapan model pembelajaran CORE ini dilakukan dengan diskusi kelompok yang menjadikan siswa saling berkomunikasi, berdiskusi, berbagi, dan berinteraksi satu sama lain untuk mewujudkan tujuan bersama. Kondisi inilah yang menjadikan model pembelajaran CORE efektif dalam meningkatkan prestasi belajar matematika siswa.

Hal penting lainnya dalam pembelajaran ini adalah penerapan strategi konflik kognitif. Lewat situasi konflik yang dihadirkan dalam LKS, siswa kemudian dapat berpikir kembali atas konsep yang telah mereka ketahui sebelumnya dan menyelesaikan konflik tersebut. Setelah konflik terpecahkan, konsep siswa yang telah ada semakin kuat dan bermakna dalam pikiran siswa. Sebagaimana hasil penelitian yang dilakukan Watson (2002) yakni penerapan strategi konflik kognitif dalam pembelajaran membantu peserta didik dalam merekonstruksi pengetahuan mereka. Dengan rekonstruksi tersebut, maka siswa akan lebih mudah mengoneksikan pengetahuan yang hendak dipelajari dengan pengetahuan yang telah dipelajari sebelumnya. Aktivitas belajar yang demikian akan memberikan kebermaknaan bagi siswa. Berdasarkan hal tersebut, maka model pembelajaran CORE-KK efektif meningkatkan prestasi belajar matematika siswa. Hasil ini sejalan dengan hasil penelitian yang dilakukan Aqiilah (2016) bahwa model pembelajaran CORE efektif ditinjau dari prestasi belajar matematika siswa.

Demikian pula untuk aspek berpikir kritis, keberhasilan model pembelajaran CORE-KK disebabkan oleh karakteristik serta tahap-tahapan dari model tersebut sangat mendukung terakomodirnya kemampuan berpikir kritis siswa. Pada model pembelajaran CORE, siswa diarahkan untuk belajar secara aktif dalam memperkuat konsep maupun prinsip matematika secara mandiri, dimana guru hanya bertugas sebagai fasilitator, motivator dan mediator. Selain itu, tahapan-tahapan dalam model CORE seperti tahap Connecting, tahap Organizing, tahap Reflecting, dan tahap Extending menuntut siswa mengeluarkan ide dan pikiran mereka serta memiliki relevansi yang kuat dengan setiap aspek kemampuan berpikir kritis. Bertalian dengan itu, Magner et al. (2011) mengungkapkan bahwa model CORE merupakan salah satu model pembelajaran yang memberikan langkah yang baik ke depan dalam integrasi berpikir kritis dan penalaran dalam mengajar dan belajar matematika.

Lebih mendalam lagi ditinjau dari kemampuan berpikir kritis siswa, strategi konflik kognitif juga memberikan sumbangsih pada peningkatan kemampuan berpikir kritis siswa. Situasi konflik yang dihadirkan pada LKS memacu siswa untuk berpikir secara mendalam dalam menelaah situasi yang dihadirkan sehingga memicu siswa merekonstruksi konsep yang mereka miliki. Hasil penelitian yang dilakukan oleh Ismaimuza (2010) menyimpulkan bahwa kemampuan berpikir kritis siswa yang memperoleh pembelajaran strategi konflik kognitif dengan model pembelajaran yang berbasis masalah lebih baik daripada siswa yang memperoleh pembelajaran konvensional. Hal yang sama pula diperoleh Lestyorini (2014) bahwa peningkatan kemampuan berpikir kritis matematis siswa yang memperoleh pembelajaran konflik kognitif lebih baik daripada siswa yang memperoleh pembelajaran konvensional dilihat dari kemampuan awal matematika (tinggi, sedang, dan rendah).

Ditinjau dari self-efficacy matematika siswa, model pembelajaran CORE-KK efektif dikarenakan dalam model pembelajaran CORE terdapat tahapan yang dapat menambah keyakinan siswa tentang konsep yang diperoleh yaitu pada tahap Reflecting serta pada tahap Extending yang melatih siswa untuk dapat menerapkan konsep yang telah mereka peroleh pada masalah yang diberikan. Tahap ini melatih siswa untuk yakin dapat menyelesaikan masalah sesuai dengan kemampuan yang mereka miliki serta yakin dengan hasil jawaban yang ditulis. Alasan ini 
sejalan dengan pendapat Bandura (2009) yang menyatakan bahwa self-efficacy berkenaan dengan keyakinan dalam kemampuan seseorang untuk mengatur dan melaksanakan rangkaian tindakan yang dibutuhkan untuk menghasilkan pencapaian yang diinginkan. Selain itu dinyatakan pula oleh Zimmerman et al. (1996) bahwa academic self-efficacy adalah penilaian seseorang mengenai kemampuannya untuk mengatur dan melaksanakan tugas-tugas yang berkaitan dengan pendidikan. Selain itu, model pembelajaran CORE dilakukan dengan diskusi kelompok sehingga memungkinkan siswa untuk saling bertukar ide, yakin dengan kemampuan mereka untuk dapat menyelesaikan permasalahan yang diberikan pada kelompok tersebut untuk dapat menyelesaikan dengan baik, sehingga hal tersebut dapat meningkatkan self-efficacy siswa. Adapun faktor yang dapat mempengaruhi selfefficacy siswa menurut Schunk (2012) antara lain: kinerja seseorang (past performance), observasi pada model (vicarious experience), bentuk dari persuasi sosial (verbal persuasion), dan tanda-tanda fisik. Kinerja seseorang dikatakan lebih meningkat ketika belajar dalam suatu kelompok dibandingkan secara individual, selain itu interaksi dalam kelompok juga lebih mendukung siswa untuk lebih ulet dalam menyelesaikan permasalahan yang diberikan dengan berbagai ide dalam kelompok tersebut.

Berdasarkan faktor tersebut, dapat dikatakan bahwa self-efficacy siswa dapat lebih baik ketika diberikan pembelajaran model CORE yang dilakukan dengan diskusi berkelompok. Lebih lanjut, strategi konflik kognitif yang diterapkan juga mempengaruhi siswa dalam kematangan konsep yang dipelajari sehingga menumbuhkan keyakinan diri atas konsep yang telah dimiliki. Hal ini sejalan dengan penelitian yang dilakukan oleh Budiawan (2017) yang menyimpulkan bahwa pengembangan efikasi diri matematik peserta didik yang memperoleh strategi pembelajaran konflik kognitif lebih baik daripada peserta didik yang memperoleh pembelajaran matematika secara konvensional. Berdasarkan ulasan-ulasan tersebut, maka semakin mempertegas bahwa model pembelajaran COREKK efektif ditinjau dari prestasi belajar matematika, kemampuan berpikir kritis, dan self-efficacy siswa.

Selanjutnya, faktor utama yang menjadi penyebab model pembelajaran CORE-KK lebih efektif dibandingkan dengan pembelajaran konvensional ditinjau dari prestasi belajar matematika, kemampuan berpikir kritis, dan selfefficacy siswa yaitu tahap-tahap pembelajaran yang menekankan keterlibatan siswa. Setiap tahap pada pembelajaran CORE memicu siswa agar lebih aktif dalam mengkonstruksi pengetahuan, serta dengan strategi konflik kognitif yang diberikan siswa dapat merekonstruksi konsep yang ada dalam pikiran siswa. Dengan penyajian $\mathrm{konflik/masalah} \mathrm{yang} \mathrm{memicu} \mathrm{konflik} \mathrm{kognitif} \mathrm{pada} \mathrm{siswa} \mathrm{yang} \mathrm{dapat} \mathrm{terselesaikan,} \mathrm{maka} \mathrm{konsep} \mathrm{yang} \mathrm{dimiliki} \mathrm{siswa}$ semakin kuat dan menjadi lebih bermakna. Hal ini berdampak pada kemampuan berpikir kritis siswa yang mengalami peningkatan. Sedangkan, pada pembelajaran konvensional yang menjadikan guru sebagai pusat informasi, sehingga membatasi keterlibatan siswa selama proses pembelajaran yang berdampak pada tidak terakomodirnya proses berpikir siswa. Hal ini bertentangan dengan prinsip belajar modern yang menitikberatkan pada keterlibatan siswa mengkonstruksi pengetahuannya sendiri. Sebagaimana yang diungkapkan oleh Moore (2012) bahwa dalam belajar siswa akan mengkonstruksi dan membangun pengetahuannya sendiri melalui pengalaman dan interaksi dengan lingkungan belajarnya. Lebih lanjut, dalam pembelajaran CORE-KK, lembar kerja siswa (LKS) dirancang dengan memberikan permasalahan matematika yang melatih siswa menyelesaikan masalah-masalah yang melibatkan konsep. Kegiatan ini memberikan siswa kesempatan untuk mendapatkan penguatan konsep. Selain itu, pada model pembelajaran CORE-KK, siswa diberikan kesempatan untuk mempresentasikan hasil diskusi kelompok kepada seluruh siswa serta adanya feedback yang berupa tanggapan siswa lain kelompok lain. Aktivitas seperti ini tidak terjadi pada model pembelajaran konvensional, dimana siswa hanya pasif mendengarkan, mencatat dan mengerjakan soal-soal latihan yang diberikan guru.

\section{SIMPULAN}

Penelitian ini menyimpulkan bahwa model pembelajaran CORE dengan strategi konflik kognitif efektif ditinjau dari prestasi belajar matematika, kemampuan berpikir kritis, dan self-efficacy siswa. Selain itu, model pembelajaran CORE dengan strategi konflik kognitif juga lebih efektif dibandingkan dengan model konvensional ditinjau dari prestasi belajar matematika, kemampuan berpikir kritis, dan self-efficacy siswa. Hal ini menunjukkan bahwa model pembelajaran CORE dengan strategi konflik kognitif dapat digunakan oleh guru sebagai salah satu referensi pembelajaran untuk meningkatkan prestasi belajar matematika, kemampuan berpikir kritis, dan self-efficacy siswa. Penelitian ini memiliki beberapa keterbatasan, di antaranya sampel yang dilibatkan kecil. Untuk itu, ke depannya peneliti menyarankan agar peneliti lain dapat mereplikasi penelitian ini dengan melibatkan populasi dan sampel yang lebih luas, sehingga dapat dilakukan generalisasi yang lebih luas terkait keefektifan model CORE dengan strategi kognitif ditinjau dari prestasi belajar matematika, kemampuan berpikir kritis, dan self-efficacy siswa. 


\section{DAFTAR PUSTAKA}

Ahmad, S. R. (2016). Pengaruh math phobia, self-efficacy, adversity quotient dan motivasi berprestasi terhadap prestasi belajar matematika siswa SMP. Jurnal Riset Pendidikan Matematika, 3(2), 259-272. https://doi.org/10.21831/jrpm.v3i2.6138

Aqiilah, A. (2016). Perbandingan keefektifan model CORE dalam pembelajaran transformasi geometri strategi berpasangan dan kelompok kecil siswa kelas IX IPA ditinjau dari kemampuan penalaran, prestasi, dan selfefficacy [Master's thesis, Universitas Negeri Yogyakarta]. https://eprints.uny.ac.id/42700/

Ayda, E., \& Widjajanti, D. (2014). Pengembangan perangkat pembelajaran teorema pythagoras dengan media berbantuan komputer.Jurnal Riset Pendidikan Matematika, 1(2), 216-226. https://doi.org/10.21831/jrpm.v1i2.2677

Bandura, A. (2009). Self-efficacy in changing societies. Cambridge University Press.

Black-Hawkins, K., Florian, L., \& Rouse, M. (2007). Achievement and inclusion in schools. Routledge. https://doi.org/10.4324/9780203945223

Budiawan, E. (2017). Meningkatkan kemampuan berpikir kritis dan kreatif matematis serta mengembangkan efikasi diri siswa SMA melalui strategi pembelajaran konflik kognitif [Master's thesis, Universitas Pasundan]. http://repository.unpas.ac.id/id/eprint/27448

Chukwuyenum, A. N. (2013). Impact of critical thinking on performance in mathematics among senior secondary school students in Lagos State. IOSR Journal of Research \& Method in Education, 3(5), 18-25. http://www.iosrjournals.org/iosr-jrme/papers/Vol-3\%20lssue-5/D0351825.pdf

Curwen, M. S., Miller, R. G., White-Smith, K. A., \& Calfee, R. C. (2010). Increasing teachers' metacognition develops students' higher learning during content area literacy instruction: Findings from the read-write cycle project. Issues in Teacher Education, 19(2), 127-151. http://education.eng.macam.ac.il/article/2872

Darojah, U. (2018). Peningkatan kemampuan berpikir kritis dan prestasi belajar PPKN siswa kelas XI melalui model pembelajaran CORE (connecting, organizing, reflecting, extending) MAN 3 Bantul. Jurnal Pendidikan Kewarganegaraan dan Hukum, 7(5), 509-516.

http://journal.student.uny.ac.id/ojs/index.php/civics/article/view/12355

Dehghani, M., Sani, H. J., Pakmehr, H., \& Malekzadeh, A. (2011). Relationship between students' critical thinking and self-efficacy beliefs in Ferdowsi University of Mashhad, Iran. Procedia-Social and Behavioral Sciences, 15, 2952-2955. https://doi.org/10.1016/j.sbspro.2011.04.221

Dymock, S. (2005). Teaching expository text structure awareness. The Reading Teacher, 59(2), 177-181. https://doi.org/10.1598/RT.59.2.7

Fisher, A. (2011). Critical thinking: A introduction (2nd ed.). Cambridge University Press.

Glass, G. V., \& Hopkins, K. D. (2008). Statistical methods in education and psychology (3rd ed.). Pearson.

Humaira, T. (2015) Peningkatan kemampuan pemahaman dan pemecahan masalah matematis, serta habits of mind siswa MTs melalui pembelajaran model CORE menggunakan strategi konflik kognitif [Master's thesis, Universitas Pendidikan Indonesia]. http://repository.upi.edu/17571/

Ismaimuza, D. (2010). Pengaruh pembelajaran berbasis masalah dengan strategi konflik kognitif terhadap kemampuan berpikir kritis matematis dan sikap siswa SMP. Jurnal Pendidikan Matematika, 4(1), 1-10. https://doi.org/10.22342/jpm.4.1.305.

Johnson, R. A., \& Winchern, D. W. (2007). Applied Multivariate Statistical Analysis. Prentice Hall.

Kemendikbud. (2014a). Peraturan Menteri Pendidikan dan Kebudayaan Republik Indonesia Nomor 58 Tahun 2014 tentang Kurikulum 2013 Sekolah Menengah Pertama/Madrasah Tsanawiyah.

Kemendikbud. (2014b). Peraturan Menteri Pendidikan dan Kebudayaan Republik Indonesia Nomor 104 Tahun 2014 tentang Penilaian Hasil Belajar oleh Pendidik pada Pendidikan Dasar dan Pendidikan Menengah. 
PYTHAGORAS: Jurnal Pendidikan Matematika, 15 (1), 2020 - 85

Sri Wahyuni Ningsih, Sugiman, Pika Merliza, Uke Ralmugiz

Kemendiknas. (2006a). Peraturan Menteri Pendidikan Nasional Republik Indonesia Nomor 22 Tahun 2006 tentang Standar Isi Untuk Satuan Pendidikan Dasar dan Menengah.

Kemendiknas. (2006b). Peraturan Menteri Pendidikan Nasional Republik Indonesia Nomor 23 Tahun 2006 tentang Standar Kompetensi Lulusan Sekolah Menengah.

Kumalasari, E. (2011). Peningkatan kemampuan pemecahan masalah matematis siswa SMP melalui pembelajaran matematika model CORE. Prosiding Seminar Nasional Pendidikan Matematika Program Pasca Sarjana STKIP Siliwangi Bandung, pp. 221-228.

Langenfeld, T. E., \& Pajares, F. (1993). The mathematics self-efficacy scale: A validation Study. Paper presented at the Annual Meeting of The American Educational Research Association, April 1993.

https://files.eric.ed.gov/fulltext/ED364413.pdf

Lee, G., \& Kwon, J. (2001). What do we know about students' cognitive conflict in science classroom: A theoretical model of cognitive conflict process. Proceeding of 2001 AETS Annual meeting, Costa Messa, pp. 309-325. https://files.eric.ed.gov/fulltext/ED472903.pdf

Lee, G., Kwon, J., Park, S. -S., Kim, J. -W., Kwon, H. -G., \& Park, H. -K. (2003). Development of an instrument for measuring cognitive conflict in secondary-level science classes. Journal of Research in Science Teaching. 40(6), 585-603. https://doi.org/10.1002/tea.10099

Lestyorini, R. D. (2014). Peningkatan kemampuan berpikir kritis matematis dan kemampuan disposisi matematis siswa SMK melalui pembelajaran konflik kognitif [Master's thesis, Universitas Pasundan]. http://repository.unpas.ac.id/id/eprint/9543

Magner, T., Soule, H., \& Wesolowski, K. (2011). P21 common core toolkit: A guide to aligning the common core state standards with the framework for 21st century skills. http://weiseteched.weebly.com/uploads/5/9/0/7/59070519/p21commoncoretoolkit.pdf

Miller, R. G., \& Calfee, R. C. (2004). Making thinking visible: A method to encourage science writing in upper elementary grades. Science and Children, 42(3), 20-25. https://digitalcommons.chapman.edu/education_articles/23/

Moore, A. (2012). Teaching and learning: Pedagogy, curriculum, and culture. Routledge.

Pajares, F. (2002). Overview of social cognitive theory and of selfefficacy. http://www.uky.edu/ eushe2/Pajares/eff.html

Pajares, F. (2005). Gender differences in mathematics self-efficacy beliefs. In A. M. Gallagher \& J. C. Kaufman (Eds.), Gender differences in mathematics: An integrative psychological approach (pp. 294-315). Cambridge University Press.

Ramadhani, E. Y., \& Kusuma, A. B. (2020). Application of CORE learning to improve mathematical connection capabilities and self-efficacy. Mathematics Education Journals, 4(1), 54-62. https://doi.org/10.22219/mej.v4i1.11470

Rosyida, F., Utaya, S., \& Budijanto, B. (2016). Pengaruh kebiasaan belajar dan self-efficacy terhadap hasil belajar geografi di SMA. Jurnal Pendidikan Geografi, 21(2), 17-28. http://journal.um.ac.id/index.php/pendidikangeografi/article/view/5903/2436

Ruggiero, V. R. (2012). The art of thinking: A guide to critical and creative thought (10th ed.). Pearson.

Santrock, J. W. (2011). Educational psychology (5th ed.). McGraw-Hill.

Schunk, D. H. (2012). Learning theories: An educational perspective (6th ed.). Pearson Education.

Sewell, A., \& George, A. S. (2000). Developing efficacy beliefs in the classroom. Journal of Educational Enquiry, 1(2), 58-71. https://ojs.unisa.edu.au/index.php/EDEO/article/view/576

Stevens, J. P. (2009). Applied multivariate statistics for the social sciences (5th ed.). Routledge/Taylor \& Francis Group. 
Susilowaty, N., \& Marpaung, M. S. (2018). Effect of CORE learning models with cognitive-conflict strategy towards the mathematics problem solving and anxiety of SMP students. Abstract Proceedings International Scholars Conference, 6(1), 289. https://jurnal.unai.edu/index.php/isc/article/view/1274

Suyatno, S. (2009). Menjelajah pembelajaran inovatif. Masmedia Buana Pustaka.

Tamalene, H. (2010). Pembelajaran matematika dengan model CORE melalui pendekatan keterampilan metakognitif untuk meningkatkan kemampuan penalaran matematis siswa sekolah menengah pertama: Studi eksperimen pada salah satu SMP Negeri di Kota Ambon [Master's thesis, Universitas Pendidikan Indonesia]. http://repository.upi.edu/9273/

Watson, J. M. (2002). Inferential reasoning and the influence of cognitive conflict. Educational Studies in Mathematics, 51, 225-256. https://doi.org/10.1023/A:1023622017006

Widoyoko, E. P. (2015). Teknik penyusunan instrumen penelitian. Pustaka Pelajar.

Yaniawati, R. P., Indrawan, R., \& Setiawan, G. (2019). CORE model on improving mathematical communication and connection, analysis of students' mathematical disposition. International Journal of Instruction, 12(4), 639654. https://doi.org/10.29333/iji.2019.12441a

Zimmerman, B. J., Bonner, S., \& Kovach, R. (1996). Developing self-regulated learners: Beyond achievement to selfefficacy. American Psychological Association. 